\title{
ON THE NECESSITY OF PHILOSOPHIZING JURISPRUDENCE. REFLECTIONS ON THE CONCEPT OF THINKING AND COGNITION BY B.N. CHICHERIN
}

\begin{abstract}
The article analyzes the concept of thinking and cognition, which is a justification for a closed selfsufficient universal system of finding true knowledge, and provides a justification for the need for philosophizing jurisprudence.
\end{abstract}

Keywords: thinking, cognition, understanding, truth, logic, metaphysics, substance, basic principles, foundations, matter, soul, mind.

\section{References}

1. CHicherin B.N. Osnovaniya logiki i metafizika. S. 1. Lit. Mir - Elektronnaya biblioteka.

2. Tihomirov P.V. Neskol'ko kriticheskih zamechanij na CHicherina. Osnovanie logiki i metafiziki. M., 1894.

3. SHapsugov D.YU. O tozhdestve i edinstve ontologii, gnoseologii i metodologii v pravovom poznanii// SHapsugov D.YU. Poznavaya blago, sebya i mir. Rostov-na-Donu, 2014.

\section{МОДЕЛИ МЕДИАТОРСТВА НА СЕВЕРНОМ КАВКАЗЕ В 1950 - 1970-Е ГОДЫ ${ }^{*}$}

\author{
Бабич \\ доктор исторических наук, Институт этнологии и антропологии \\ Ирина \\ РАН (119334, Россия, г. Москва, Ленинский пр-т, 32-А). \\ Леонидовна E-mail: babi7chi@yandex.ru \\ Плиев кандидат исторических наук, Институт этнологии \\ Абдурахим и антропологии РАН (119334, Россия, г. Москва, Ленинский пр-т, \\ Ахмедович 32-A). E-mail: babi7chi@yandex.ru
}

\begin{abstract}
Аннотация
Статья посвящена анализу формирования моделей медиаторства в 1950-70-е г2., когда советская власть в послевоенное, хрущевское время обратило внимание на горский адат. Исследование опирается на анализ уголовных дел Верховных судов КабардиноБалкарской и Чечено-Ингушской и другие архивные и полевые материалы. В статье рассмотрены принципы создания советских примирительных комиссий в Чечне и Ингушетии и основы медиаторства среди адыгов и осетин, а также соотношение кровной мести и советского судопроизводства.

Ключевые слова: Северный Кавказ, медиаторство, примирительные комиссии, советская власть, старики.

Введение

В конце 1950-х годов судебная политика советской власти по отношению к адату меняется. Сначала в годы хрущевской оттепели, затем в застойные годы советская печать и органы Министерства юстиции заговорили о наличии у северокавказских горцев до революции полезных адатов. Задачей советских судебных органов стало выделение сохранившихся полезных норм адата (почитание стариков, медиаторство, охрана общественного порядка и собственности), их развитие и по-прежнему решительная борьба с вредными адатами (бесправие и забитость женщины, кровная месть).
\end{abstract}

\footnotetext{
* Публикуется в соответствии с планом научно-исследовательских работ Института этнологии и антропологии РАН.
} 
Цель статьи - на основе анализа уголовных дел Верховных судов КабардиноБалкарской и Чечено-Ингушской АССР в 1950-70-е годы и выявленных авторами архивных материалов проанализировать формирование моделей медиаторства в исследуемый период. Мы уже изучили примирительные практики на Северном Кавказе в 192030-е гг. и планируем рассмотреть, как эти практики трансформировались в послевоенное, хрущевское время [1]. 1950-1970-е годы - наименее изученный период в истории медиаторства на Северном Кавказе. Мы можем назвать работы М.С.-Г. Албогачиевой, И.Л. Бабич, в которых отчасти исследуется этот период правовой истории горцев [2].

В 1950-60-е годы в советской правовой политике и идеологии произошли изменения: с одной стороны, принятый в 1960 г. новый Уголовный кодекс РСФСР значительно ужесточил меры борьбы с преступлениями, совершаемыми на почве кровной мести, и другими пережитками местных обычаев, а с другой, появилось разграничение между полезными и вредными обычаями (или адатами). В этот период во многих сельских районах Северного Кавказа при сельсоветах стали создавать советы старейшин. Они включали в себя от 3 до 15 мужчин пенсионного возраста [3]. Перед ними стояла задача помогать народным судам и сельсоветам в поддержании общественного порядка в колхозе (совхозе), регулировать столкновения между его членами, по возможности предупреждать случаи кровной мести, следить за поддержанием в порядке дорог, оросительных каналов, сельских клубов и не допускать расхищения колхозной собственности ${ }^{1}$. В Северной Осетии такие советы действовали в нескольких десятках селений на равнине и в предгорьях. В отличие от дореволюционных органов сельского самоуправления, которые они внешне копировали, советы старейшин в советских республиках Северного Кавказа играли чисто консультативную роль при местных народных судах и исполкомах сельсоветов. Гораздо большую власть в это время приобрели сельские сходы и особенно старики-примирители, сохранившие знание адатных норм. Наиболее авторитетных мужчин села, чье мнение могло быть принято, стали привлекать в качестве посредников-медиаторов. Власти смотрели на их полулегальное существование сквозь пальцы.

Советские примирительные комиссии в Чечни и Ингушетии

В 1960-е годы советская администрация на Северном Кавказе попыталась вновь возродить примирительные комиссии. Такие комиссии были созданы в Чечне, Ингушетии, Аджарии, Дагестане. В конце 1950-начале 1960-х годов в северокавказских обществах наблюдалось своеобразное сочетание традиционных форм примирения и деятельности советских судебных органов власти по урегулированию конфликтов. Однако в эти годы традиционное медиаторство не всегда срабатывало. Иногда после того, как состоялось примирение, все равно совершалась кровная месть, т.е. примирительная функция адата иногда не «срабатывала». Приведем пример. В 1963 г. житель Урус-Мартанского района (Чечня) А.Б. в качестве мести убил Х.Г. и одновременно пытался убить его двоюродного брата М.А., нанеся ему тяжелые телесные повреждения. Дело рассматривалось в советском суде, виновный был осужден, тем не менее чтобы «окончательно примирить» эти фамилии, почетные старики обратились к народным обычаям. Им удалось примирить враждующие стороны, однако только на время. Через некоторое время осужденный в советском суде после того, как вышел из тюрьмы, был убит ${ }^{2}$.

Советских и партийных чиновников не устраивало и то, что во время примирения осуществлялись выплаты компенсаций в больших размерах. Это мы узнаем из материалов VIII-й Чечено-Ингушской областной партийной конференции (январь 1960 г.) ${ }^{3}$. В апреле 1960 г. на II-м Пленуме обкома партии председатель Верховного Совета Чечено-

\footnotetext{
${ }^{1}$ Архив Института Этнологии и антропологии РАН (далее - АИЭА). Тетр.2. Оп.6. Д.15; Тетр.4. Оп.7. Д.1.

${ }^{2}$ Архив Верховного Суда Чечено-ингушской АССР (далее АВСЧИАССР). Д.2-90. Л.6, 116.

3 Архив Областного комитета коммунистической партии Чечено-Ингушской АССР (далее АОК ЧИАССР). Ф.1. Оп.20. Д.2, Л.339.
} 
Ингушской республики И.А. Алмазов остановился на деятельности «адатских (медиаторских) судов, основной мерой наказания которых являлись высокие штрафы». Поэтому были приняты меры по изменению ситуации. Республиканские власти создали свои, государственные примирительные комиссии у чеченцев и ингушей, которые контролировались республиканскими органами власти. Многие партийные деятели занялись примирением враждующих сторон. Так, в селе Ново-Чиркей (Дагестан) в 1958 г. в результате личного вмешательства первого секретаря района Алиева было достигнуто примирение между кровниками (чеченцами и дагестанцами), и кровная месть не состоялась 1 . По инициативе директора совхоза в сел. Старо-Юрт (Чечня) были предотвращены два случая кровной мести. В двух враждующих семьях убитого и убийцы выросла молодежь. С ней директор и вел беседы, в результате чего состоялось примирение 2 . Таким образом, партийные и советские органы решили взять на себя роль «стариков-посредников». Таким образом, традиционное примирение в Чечне и Ингушетии постепенно трансформировалось в «советское посредничество»: иногда это было удачно, иногда нет. Главное отличие советского примирения от традиционного - отсутствие выплаты компенсаций за причиненный физический ущерб.

На упоминавшейся выше VIII-й Чечено-Ингушской областной партийной конференции ${ }^{3}$ было принято решение в связи с большим количеством случаев кровной мести организовать Республиканскую и районные примирительные комиссии «по ликвидации кровничества, в задачи коих входит окончательная ликвидация пережитка кровной мести и примирение враждующих фамилий» ${ }^{4}$. В Республиканскую комиссию вошло девять человек во главе с заместителем председателя Президиума Верховного Совета ЧеченоИнгушской АССР А.-В.Т. Тепсаевым 5 . Членами комиссии стали работники редакции республиканской газеты, профсоюзов, прокуратуры, рабочие, пенсионеры. Таким образом, было нарушено одно из главных адатных правил: посредниками должны быть исключительно авторитетные пожилые люди. Для членства в советской комиссии определяющим был должностной фактор 6 .

Кроме Республиканской комиссии, которая должна была рассматривать дела, касающиеся всей республики, при всех районных и сельских советах были созданы аналогичные комиссии: районные и сельские примирительные комиссии, в чье ведение входило рассмотрение более мелких конфликтов и ссор. В функции комиссий всех уровней входило выявление и примирение кровников, составление соответствующих документов о примирении и т.д.

Примирительные комиссии всех уровней Чечни и Ингушетии сразу же приступили к работе. Прежде всего, ими был составлен список всех имеющихся в пределах Чечено-Ингушской АССР конфликтов, связанных с кровной местью: всего таких случаев было 314. За период с февраля по ноябрь 1960 г. в Чечено-Ингушетии с помощью Примирительных комиссий удалось примирить практически половину кровников из имею-

\footnotetext{
1 АОКЧИАССР. Ф.1. Оп..10. Д.4. Л.333. Л. 182.

2 АОКЧИАССР. Ф.1, Оп.13. Д.8. Л.288.

${ }^{3}$ АОКЧИАССР. Ф.1. Оп.20. Д.2. Л.339.

4 Обращение ко всем трудящимся чеченцам и ингушам // Материалы Президиума Верховного Совета Чечено-Ингушской АССР; АОКЧИАССР. Ф.1. Оп.20. Д.2. Л.339.

5 АОКЧИАССР. Ф.1. Оп.20. Д.13. Л.150-151.

6 В состав первой Республиканской примирительной комиссии вошли следующие лица: председатель - A-B.T. Тепсаев (зам. председателя Президиума Верховного Совета Чечено-Ингушской АССР), секретарь комиссии - М. Льянов (редактор газеты «Сердало»), члены комиссии: - С.С. Сидельников (председатель Облсовпрофа), М.Ш. Шотаев (пенсионер Курчалоевского района), М.А. Кебиев (директор Веденского райлесопитомника), С.С. Бузуркиев (пенсионер из Малгобекского района), М-С. А-Х. Нальгиев (рабочий совхоза «Назрановский»), Магомерзоев (нефтяник, пенсионер из Октябрьского района), А.Я. Романов (прокурор республики). Члены комиссии утверждались на Бюро обкома партии.
} 
щихся списков (157 конфликтов). Например, в Сунженском районе летом 1960 г. произошло убийство И. В течение двух месяцев 60 человек из фамилии виновного не могли работать в колхозе, так как опасались совершения над кем-либо из них кровной мести со стороны родственников потерпевшего И. Примирительная комиссия активно работала по этому делу и ей удалось примирить стороны ${ }^{1}$.

ЦК КПСС выделило 30 тыс. руб. в качестве субсидии для ускорения работы Примирительных комиссий в Чечне и Ингушетии. Выделенные средства расходовались на обеспечение членов Комиссии транспортом для поездок по селениям.

25 августа 1960 г. состоялось первое заседание Республиканской примирительной комиссии при Президиуме Верховного Совета Чечено-Ингушской АССР. Каждый член Республиканской комиссии должен быть контролировать «уровень конфликтогенности» в одном из районов Чечни, а председатель Комиссии И.Л. Алмазов занимался общим надзором работы всех районных примирительных комиссий. На этом заседании председатели районных примирительных комиссий отчитывались о проделанной за полгода работе. Так, председатель комиссии в Шалинском районе рассказала, что она приступила к работе лишь 25 апреля. За 4 месяца в районе было выявлено 30 враждующих фамилий. Началась работа с родственниками враждующих сторон, результаты которой были таковы: удалось 9 фамилий примирить, а остальные 21 - дали согласие на примирение2. Председатель комиссии в Веденском районе озвучила их успехи: зарегистрировано было 19 враждующих семей: 7 - прошли примирение, а 5 - дали согласие на эту процедуру. В Советском районе из 36 выявленных враждующих семей только две были примирены и две подготовлены к примирению. Наибольшее количество враждующих семей - 87 было зарегистрировано в Ачхой-Мартановском районе. В этом же районе обнаружились самые плохие показатели по примирению: только в 8 случаях оно было успешно достигнуто.

Через четыре года - по данным на 1 июля 1964 г. успехи районных примирительных комиссий были таковы: всего в Чечне было примирено 424 враждующих между собой фамилий, по данным на 1 января 1965 г. - таких семей было уже 470.

Помимо деятельности районных и сельских примирительных комиссий советская администрация проводила общественные сходы, на которых с жителями обсуждались «пережитки прошлого». Так, 19 марта 1960 г. жители сел. Экажево, а затем 18 апреля жители сел. Сурхахи провели сельские сходы, на которых были приняты два решения: о прекращении кровной вражды между жителями своих селений и о прекращении практики уплаты тоам («примиренческих»). Советская власть, таким образом, загоняла население в «угол», поскольку выплата компенсации - ключевой этап в примирении кровников, без него оно просто не могло состояться.

Отметим, что, как пишут советские чиновники, уже на самом сельском сходе в сел. Экажево некоторые участники примирились со своими кровниками, например, 80летние старики М. А. и К. С., а также М. С., у которого отец был убит еще до его рождения. На сходе он сказал следующее: «Я прощаю кровь своего отца, хотя мне и трудно не иметь в дальнейшем кровничества» ${ }^{3}$. На сходе в сел. Экажево враждующие между собой люди, пожимая друг другу руки, заверяли, что отныне они являются братьями, а не врагами. Многие из них просили при этом представителей власти передать им на перевоспитание осужденных на разные сроки за драку между собой, что и было сделано. После этого родственники шести осужденных юношей примирились ${ }^{4}$. Важно подчеркнуть, что принятые

\footnotetext{
1 АОКЧИАССР. Ф.1. Оп.20. Д.13. Л.150-151.

2 Стенограмма заседания Комиссии по ликвидации кровничества при Президиума Верховного Совета Чечено-Ингушской АССР, 25 августа 1960 г. // Материалы Президиума Верховного Совета ЧеченоИнгушской АССР.

3 АОКЧИАССР. Ф.1. Оп.20. Д.6. Л.75.

4 АОКЧИАССР. Ф.1. Оп.20. Д.6. Л.75.
} 
на сходе решения в дальнейшем не нарушались. В противном случае общество могло отказаться от отступников: «Если вы не соглашаетесь с нами, то мы от вас отказываемся, не будем иметь родства и хоронить умершего». Таким образом, фактически использовалась традиционная норма адата - «бойкот» по отношению к тем, кто отказывался мириться.

18 апреля 1960 г. на сельском сходе в сел. Сурхахи с участием Республиканской примирительной комиссии, партийных и советских работников, работников прокуратуры и милиции, а также жителей села (присутствовало 970 чел.) началась процедура повторного примирения. Вышел на трибуну житель сел. Сурхахи М. А. и начал говорить: «Я на днях примирился с Х., простил ему два убийства. Я прошу вас, сурхахинцы, давайте ликвидируем вражду. 44 года между нами и Б. продолжалась вражда, ни они не хотели убивать, и не мы, но ради национальных «обычаев» мстить - мы продолжали вражду». Другой житель этого селения И. А. добавлял: «Между нами (кровниками - однофамильцами А. - прим. А.П.) уже 3 года как нет вражды, но злые слухи искусственно устраивают между нами кровную месть». Сельский сход в присутствии важных и почетных гостей закончился всеобщим примирением кровников, рукопожатиями, объятиями. Было примирено шесть враждующих семей. На сходе было принято следующее постановление:

«1. Навсегда покончить со всеми имеющимися случаями кровной мести и в дальнейшем не допустить ни одного нового случая.

2. Бойкотировать тех, кто не хочет согласиться с решением настоящего схода и просить органы применить к ним самые строгие меры, вплоть до выселения с семьями в отдаленные районы страны.

3. Просить правительство о высшей мере наказания - расстреле для убийцы, при каких бы обстоятельствах он не совершил убийство»1.

В этом постановлении, как нам представляется, проявляется одна важная черта нового, «советского» примирения, а именно: замена совершения кровной мести (в форме убийства) на «узаконенное» убийство путем назначения согласно УК СССР высшей меры наказания - расстрела. Таким образом, население переносило процесс совершения мести с себя на «государство». Не случайно, в постановлении так говорится: «при каких бы обстоятельствах он не совершил убийство», поскольку бывают смягчающие обстоятельства согласно УК СССР, благодаря которым виновному назначали более мягкое наказание, чем расстрел, однако население это «не устраивало» - только расстрел.

В это же время состоялось примирение двух семей в сел. Беной (Чечня). 25-летний житель примирился с убийцей своего отца (оно произошло давно, когда мальчику было всего полгода). Молодой человек говорил так: «Я рано не знал ласки отца. Когда я видел, что отцы ласкают своих детей, во мне вскипала злоба на тебя, убийцу моего отца. Я не думал, что есть на свете такая сила, которая заставит меня простить тебя, но ради Советской власти, которая возвратила меня на Родину, я прощаю тебе от всей души». В ответ 70-летний старик с рыданием упал перед сыном убитого на землю и обхватил его ноги руками. Тот поднял его и пожал ему руку. Перед всем народом старик попросил у своего бывшего кровника разрешения заменить ему отца. Тот дал согласие и объявил, что отныне убийца его отца будет его вторым отцом. Оба крепко обнялись 2 .

27 апреля 1960 г. под руководством Республиканской примирительной комиссии состоялся сельский сход в сел. Гойты Урус - Мартановского района (Чечня). На сходе состоялось примирение двух враждующих фамилий, чьи родственники находились

\footnotetext{
1 Протокол схода жителей с. Сурхахи Назрановского района 18 апреля 1960 г.// Материалы Президиума Верховного Совета Чечено-Ингушской АССР.

2 Справка о предварительных итогах работы примирительных комиссий по кровничеству в ЧеченоИнгушской АССР // Материалы Президиума Верховного Совета Чечено-Ингушской АССР.
} 
во вражде с 1918-1919 гг., когда были убиты их близкие. На сходе было принято следующее постановление:

«1. Ликвидировать кровную месть среди Чечено-Ингушского народа.

2. Лиц, отказывающихся от примирения, передавать органами власти, чтобы последние лишали их права жительства в данном месте с конфискацией имущества» 1. Опять-таки мы видим в постановлении сельского схода санкции против тех, кто отказывал мириться «по-советски», - принудительное выселение за пределы района.

30 августа 1960 г. в сел. Автуры Шалинского района (Чечня) состоялся сельский сход, на котором присутствовало 143 чел. Советская администрация поставила вопрос «0 борьбе со старыми вредными пережитками». Все выступавшие «благодарили партию и правительство за внимание к малым народам, за принятое решение о борьбе с пережитками прошлого». Сельский сход принял следующее постановление:

«1. Кровно враждующих граждан, кто бы ни был, в случае отказа от примирения, если он работает, снять с работы и лишить имеющиеся у него приусадебного участка, а также категорически запретить ему выпас скота индивидуального пользования на совхозной земле.

2. Сопротивляющегося ликвидации кровничества и других вредных пережитков бойкотировать, покрывать позором, как носителя вредных пережитков, и просить правительство применить к нему 195 ст. УК с выселением его за пределы Чечено-Ингушской ACCP.

3. В целях окончательной ликвидации кровничества и других видов вражды просить правительство к убийце применять высшую меру наказания, независимо от причины убийства»².

В этом постановлении мы сталкиваемся с новыми видами санкций против тех, кто не хотел мириться «по-советски»: снятие с работы, лишение приусадебного участка, запрет на выпас частного скота на совхозной земле. Это очень серьезные аспекты советской политики по отношению к ослаблению кровной мести. Введение новых методов борьбы с враждой в Чечне и Ингушетии лишь доказывало наличие безусловных трудностей в этом деле.

\section{Медиаторский суд}

Медиаторский суд или советские государственные примирительные комиссии как правовые или общественные институты в 1950-70-е гг. отсутствовали в исследуемый период на Северо-Западном и Центральном Северном Кавказе: в Адыгее, Кабардино-Балкарии, Северной Осетии. Однако многие дела, связанные с убийствами или похищением девушек, у адыгов и осетин продолжали «закрываться» без осуждения виновных. В партийных документах 1950-х годов говорится о терпимом отношении к таким явлениям в Северной Осетии ${ }^{3}$.

Сельчане скрывали происходившие в их селении конфликты, которые старались урегулировать с помощью третейского посредничества, которое продолжало в незначительной степени неофициально бытовать в 1940-1950-е годы. Так, на одном из собраний парторганизации Северной Осетии говорилось, что «есть случаи, когда отдельные люди пытаются культивировать примирение кровников путем выплаты компенсации и организации большого хиста, т.е. поминок» ${ }^{4}$.

\footnotetext{
1 Протокол общего схода граждан с. Гойты, Урус-Мартановского района 27 апреля 1960 г. // Материалы Президиума Верховного Совета Чечено-Ингушской АССР.

2 Протокол общего схода граждан с. Автури Шалинского района 30 августа 1960 г. // Материалы Президиума Верховного Совета Чечено-Ингушской АССР.

${ }^{3}$ ЦГА РСО-Алания. Ф.1. Оп.1. Д.25. Л.22; Д.586. Л. 27, 30-31; Оп.13. Д.814. Л.118.

${ }^{4}$ ЦГА РСО-Алания. Ф.1. Оп.1. Д.586. Л.77.
} 
Степень распространения данной правовой традиции на Северо-Западном и Центральном Кавказе в 1950-1970-е годы определялась не только характером политики советской администрации по отношению к горским традициям, но и эволюцией собственно обычного права горцев, которое лишь в незначительной степени продолжало неофициально функционировать у осетин. Так, известно, в Северной Осетии в 1950-е годы применялась выплата компенсации при урегулировании исходных конфликтов, во время которых произошло убийство, а также при похищении и изнасиловании девушек 1 .

В целом, в течение 1950-1970-х годов политика республиканских властей Кабардино-Балкарии, Адыгеи и Северной Осетии состояла в невмешательстве в сельскую судебную практику. У адыгов было достаточно свободы в выборе формы урегулирования конфликтов. В тот период сложилась следующая судебная практика: советские народные суды рассматривали все происходившие в селениях уголовные преступления, главным образом убийства, разбирали дела, связанные с причинением материального ущерба, а также иски о разводах ${ }^{2}$. Сразу же после происшествия органы милиции составляли рапорт, который отсылался в следственные отделы, а затем в советский народный суд. В основном это правило соблюдалось в отношении умышленных убийств. Если же произошла драка, в результате которой было нанесено незначительное ранение, органы милиции не всегда строго выполняли свои обязанности, предоставляя потерпевшему и виновному урегулировать свой конфликт с помощью медиаторов. Иногда бывало и так. Сразу же после происшествия потерпевший или его родственники подавали заявление в суд или милицию, но позже конфликт урегулировали с помощью медиаторов и забирали свое заявление, обращаясь с просьбой о прекращении рассмотрения конфликта. Судебные и милицейские органы, как правило, соглашались с этим ${ }^{3}$.

Работники местных советских судов, хорошо знающие адыгские правовые традиции, не препятствовали конфликтующим сторонам рассматривать свой спор в медиаторском суде. Тем не менее, как показывают этнографические данные, если в исходном конфликте произошло убийство, в советские годы нельзя было избежать рассмотрения дела в советском суде. Виновному определяли меру наказания в соответствии с Уголовным кодексом РСФСР. В то же время медиаторы занимались примирением родственников виновного и потерпевшего. При успешном его завершении оно позволяло, во - первых, ослабить или исключить установление кровных или враждебных отношений между сторонами, и во-вторых, смягчить наказание, которое определялось советским судом 4 .

При рассмотрении дел о причинении физического ущерба медиаторы руководствовались, как и прежде, адыгским или осетинским адатом, и применяли следующие нормы: устройство примирительного угощения; подарки потерпевшей стороне; выплата компенсации; выселение семьи виновного на временное или постоянное жительство в другое место 5 .

При умышленных убийствах, как свидетельствует судебный архивный материал, родственники виновных, как правило, даже не пытались через посредников начинать переговоры о примирении с родственниками потерпевших. Последние обычно велит себя очень агрессивно и в большинстве случаев обращались к российским судьям с просьбой, а порой и с требованием об определении виновному самого строго наказания, вплоть до расстрела. Иногда во время судебного процесса они заявляли, что отказываются от получения материальной компенсации в пользу вынесения российским судом

\footnotetext{
1 Фонд партии. ЦГА РСО-Алания. Ф.1. Оп.1. Д.586. Л.77.

${ }^{2}$ АИЭА. Тетр.1.0п.1. Д.3-6; Оп.4. Д.12; Оп.5. Д.15; Тетр.2. Оп.7. Д.17.

${ }^{3}$ АИЭА. Тетр.1.Оп.2. Д.9; Оп.1. Д.1; Тетр.4. Оп.7. Д.1; Оп.8. Д.4; Оп.5. Д.1.

${ }^{4}$ АИЭА. Тетр.4. Оп.7. Д.2; Оп.8. Д.4; Оп.6. Д.1.

5 Фонд партии ЦГА РСО-Алания. Ф.1. Оп.1. Д.586. Л.77.
} 
смертного приговора виновному1. Так, мать убитого осетина назвала обычай традиционного примирения «дурацким законом», подчеркивая, что обращение к нему возможно только при причинении неумышленного физического ущерба во время аварий на дорогах: злой умысел «прощать нельзя». Она попросила Верховный суд Северной Осетии, куда поступило дело, передать его на рассмотрение в другую северокавказскую республику и таким образом оно попало в Верховный суд КБР. Во время судебного заседания женщина потребовала от суда рассмотреть дело не по «нашим обычаям», а по справедливости, чтобы виновный понес «справедливую кару» ${ }^{2}$.

В осетинском обществе редко, но все-таки применялась и такая норма обычного права как выселение виновного: по традиции семья виновного должна выселиться, если она не может помириться с родственниками потерпевшего. Например, в сел. СурхДигора в середине 1960-х годов некто Гоб. поссорился с молодым человеком из того же селения Гег. и убил его в драке. Убийцу судили в народном суде и приговорили к расстрелу. Вскоре после вынесения судебного решения состоялся сход членов местного колхоза. Он постановил для прекращения кровной вражды выселить из селения весь род виновного, состоящий из семей братьев и сестер убийцы. Гоб. и его родственники, не пытаясь опротестовать решение схода в народном суде или сельсовете, продали дома и переехали в г. Моздок. До сих пор их бывшие односельчане, оказавшись в городе, отказываются от всяких контактов с родственниками убийцы. Или другой случай. Молодой колхозник из Южного поселка в 1970 г. умышленно зарубил топором своего отца, с которым он состоял в длительной ссоре. Убийца подвергся двойному осуждению. Народный присудил его к 7 годам тюрьмы. По выходе на свободу убийца подвергся своего рода «остракизму» со стороны родственников и всей сельской общины. Все отношения с ним были прерваны, и он был вынужден поселиться на окраине селения 3 .

Советский суд и кровная месть

В конце 1950-х-начале 1960-х годов советской правосудие обратило внимание на уголовные дела, связанные с кровной местью. Нам удалось проанализировать такие дела, полученные из архивов Верховных Судов Кабардино-Балкарии и Чечено-Ингушской АССР. Рассмотрим описанные в них ситуации.

В 1963 г. житель Урус-Мартанского района (Чечня) А.Б. в качестве мести убил Х.Г. и одновременно пытался убить его двоюродного брата М.А., нанеся ему тяжелые телесные повреждения. Дело рассматривалось в Верховном суде Чечено-Ингушской АССР 13 июля 1963 г.: за убийство Х.Г. и нанесение тяжких повреждений А.И. виновный А.Б. был приговорен к расстрелу. Однако уже 20 августа 1963 г. дело было пересмотрено судебной коллегией по уголовным делам Верховного суда РСФСР, которая изменила приговор: смертная казнь была заменена 15 годами лишения свободы с отбыванием срока в исправительно-трудовой колонии усиленного режима 4 .

Проанализируем это уголовное дело: как нам представляется, два обстоятельства способствовали совершению второго преступления: во-первых, слишком скорое возвращение виновного домой из заключения, и, во-вторых, несоблюдение традиционных норм адата, согласно которому, после совершения примирения, вражда заканчивалась. Это свидетельствует о безусловной трансформации традиционного права чеченцев и ингушей в советское послевоенное время.

Приведем другой пример. 14 мая 1961 г. житель Ачхой-Мартановского района (Чечня) М. находился на свадьбе, во время которой в нетрезвом виде нанес ножевые ранения братьям А. и М. После этого раненные братья избили М. В тот же день 33-летний

\footnotetext{
${ }^{1}$ Архив ВС КБР. Д. 613, 8809.

2 Архив ВС КБР. Д. 22041.

3 Полевые материалы Л.К. Гостиевой. Северная Осетия. 2000 г.

${ }^{4}$ АВСЧИАССР. Д.2-90. Л.146. 170.
} 
житель, брат М. - Р. пришел к дому братьев А. и М. с целью совершения мести. Его увидел находящийся поблизости работник милиции, который сделал предупредительный выстрел. Р. нанес ножевое ранение постороннему лицу А. После этого работник милиции его задержал. Во время задержания Р. нанес ножевое ранение и ему ${ }^{1}$. Таким образом, Р. причинил телесные повреждения лицам, не виновным в первичном преступлении. Дело рассматривалось в Верховном суде Чечено-Ингушской АССР. 11 ноября 1961 г. суд классифицировал действия Р. по статьям 15, 102 п. «К», 191, 112 ч.2 УК РСФСР2. По совокупности совершенных преступлений Р. был приговорен к восьми годам лишения свободы с отбыванием в трудовой колонии усиленного режима ${ }^{3}$.

Приведем еще один пример. 18 сентября 1962 г. Верховный суд ЧеченоИнгушской АССР рассмотрел дело по обвинению нескольких жителей Веденского района (Чечня) - двух братьев: 34-летнего У.М. и 29-летнего М.М., а также 34-летнего Ш.Ю., совершивших убийство двух лиц - С.Ю., Х.К. на почве кровной мести. Один из участников уголовного дела - 34 летний У.М. уже был ранее судим (1949 г., ст.182 п.1 УК РСФСР) 4 Ранее авторитетным старикам в мае 1961 г. удалось примирить, как сказано в следственном деле, «согласно местным обычаям». Однако М.М. и его брата У.М. это примирение не устроило. И было совершено убийство 5 . Вышеописанный случай свидетельствует, что причиной конфликта, как и в предыдущем случае, было оскорбление женской чести. Вражда продолжилась и после примирения сторон, произведенного стариками по местным обычаям. Примирение было нарушено убийством. Это свидетельствует о том, что в этот период традиционные нормы примирения уже не всегда были эффективны.

Обратимся еще к одному конфликту, в результате которого произошло преступление на почве кровной мести. Две фамилии Т. и Д. состояли во враждебных отношениях с мая 1937 г.: член рода Д. подрался с членом рода Т. (Д.Т.) и его другом (Б.Ю.) нанеся им ножевые ранения. Причем на суде ему удалось доказать свою невиновность, а тех, кого он ранил, даже суд посадил в тюрьму. Д.Т. вскоре умер. Родственники из рода Т. все время упрекали брата потерпевшего, что он не отомстил виновному - убийце его брата. Через много лет, в 1961 г. в 10 часов вечера 35-летний М.Т. (брат потерпевшего), будучи в нетрезвом состоянии, пришел на квартиру к жителю Веденского района (Чечня) - 33летнему К.Д., и выстрелом из малокалиберной винтовки убил его ${ }^{6}$ Дело рассматривалось выездной сессией Верховного суда Чечено-Ингушской АССР 11 июня 1962 г. М.Т. был признан виновным по ст. 102 п. «К» и «л» УК РСФСР (умышленное убийство, совершенно на почве кровной мести и совершенное особо опасным рецидивистом). М.Т. был признан особо опасным преступником и суд приговорил его к высшей мере наказания расстрелу.

Обратим внимание на некоторые обстоятельства данного дела: во-первых, в этом деле мы видим очень длительный срок вражды - первичное преступление датируется 1937 г., совершение мести - 1961 г. Во-вторых, в данном случае произошло несоблюдение традиционного этикета «уважения потерпевшей стороны», которое выразилось в том, что К.Д. нанес ножевые ранения двум человек, которых потом и осудили. В обще-

\footnotetext{
1 АВСЧИАССР. Д 2-64. Л.1.

2 ст.15 - Ответственность за приготовление к преступлению и за покушение на преступление; ст.102 п. «К» - Умышленное убийство при отягчающих обстоятельствах, совершенное на почве кровной мести (лишение свободы на срок от восьми до пятнадцати лет со ссылкой или без таковой или смертной казнью); ст. 191 - Сопротивление представителю власти или представителю общественности, выполняющему обязанности по охране общественного порядка.

ст. 112 - Умышленное легкое телесное повреждение или побои.

3 АВСЧИАССР. Д.2-90.

${ }^{4}$ АВСРФ. Д. 23-02-41. Л. 235.

${ }^{5}$ АВСРФ. Д. 23-02-41. Л. 236-237.

${ }^{6}$ АВСЧИАССР. Д. 2-97. Д.2-33. Л.33, 259.
} 
ственной правовой идеологии чеченцев и ингушей сурово осуждались те, кто не проявлял требуемой адатом скромности по отношению к потерпевшим. Тем более осуждались те, кто на суде позволяют себе открыто заявлять о своей невиновности в присутствии потерпевшей стороны. В-третьих, родственники применили норму адата - упрека (тІихтохам) - важного побудительного повода к осуществлению акта кровной мести.

Приведем еще одно дело. 6 мая 1962 г. был убит пожилой житель Назрановского района Л.М.К. В момент нападения он проходил по улице вместе с М.И.К. ${ }^{1}$ Обстоятельства дела были таковы: они оба (Л.М.К. и М.И.К.) 17 марта 1962 г. приехали из Казахстана, где они тогда еще проживали, на Родину с тем, чтобы примириться с сыновьями их кровника - Б.Т.К., которые проживали в Дигорском (Осетия) и Назрановском (Ингушетия) районах. Конфликт между ними начался в 1940 г.: Н.К. и С.К. - члены фамилии К. убили собаку Б.Т.К. Через месяц в порядке отмщения Б.Т.К. совершал кражу лошадей у фамилии К.

Данный конфликт стали разбирать почетные старики. Старики долго уговаривали Л.М. К. В конце концов он согласился принять свою лошадь без «додачи» 2 . В соответствии с нормами обычного права ингушей и чеченцев при урегулировании подобных краж похититель должен был вернуть владельцу не только украденное, но и уплатить определенную сумму денег за «нанесение оскорбления, унижения» и т.д. Невзыскание штрафа считалось трусостью и подлежало осуждению общественностью, тем более, что такая компенсация рассматривалась как наказание, которое могло предотвратить подобного рода преступления.

В 1942 г. между семьями был другой конфликт: У. и И. - члены фамилии К. украли кукурузу. Б.Т.К. каким-то образом узнал, кто вор, и он выдал воров хозяину кукурузы И.Т.У. У.К. «принял присягу», что в течение трех дней убьет Б.Т.К., что и было сделано в 1942 г. Между семьями установились кровно-враждебные отношения. Причем, потерпевший и виновные имели одну фамилию - К., но они не были близкими родственниками, а были однофамильцами.

У.К. и И.К. умерли в Казахстане. У.К. являлся двоюродным братом Л.М.К., а И.К его племянником. Поэтому Л.М.К. и приехал мириться с сыновьями убитого Б.Т.К. - Су. и Са.

Примирительная комиссия начала работу, но не имела успеха. Са. вначале вообще отказывался от примирения, боясь насмешки, упрека со стороны общества. Он так говорил: «люди будут смеяться, что я пропиваю отцовскую кровь...», но потом согласился при условии, что согласится и его брат Су. Но вскоре и Са. отказался мириться, и убил Л.М.К. Он был признан судом виновным в совершении преступления и приговорен к высшей мере наказания - расстрелуз ${ }^{3}$ Верховный суд РСФСР утвердил приговор, однако Президиум Верховного совета РСФСР, рассмотрев дело 12 июня 1963 г., помиловал С.К., заменив смертную казнь 15 годами лишения свободы ${ }^{4}$.

Опираясь на данные Верховного суда КБР, проанализируем причины, лежащие в основе убийств на почве мести у адыгов. Из трех имеющихся в архиве подобных дел два убийства были совершены в качестве мести за убийство, а одно - по причине многолетних неприязненных отношений. Рассмотрим эти дела.

Первая ссора началась в 1960-е годы, когда в сел. Лечинкай жили соседи: один, 50 летний М.Б., работал лесником и осуществлял контроль за использованием лесного участка, а другой, подросток Х.К., вместе со своими братьями, такими же подростками занимался хищением подконтрольного М.Б. леса. Лесник часто составлял на подростков протоколы о фактах совершения ими воровства, в результате чего между соседями уста-

${ }^{1}$ АВСЧИАССР. Д. 2-97. Д. 2-13. Л.1.

${ }^{2}$ АВСЧИАССР. Д. 2-97. Л. 3, 7.

${ }^{3}$ АВСЧИАССР. Д. 2-97. Л. 96 об.

${ }^{4}$ АВСЧИАССР. Д. 2-97. Л.116. 
новились неприязненные отношения. Х.К. подрос и в 19-летнем возрасте решил отомстить леснику. Он пришел в лес, дождался появления лесника, который, к несчастью, был со своим приемным сыном, и убил их обоих топором ${ }^{1}$.

В двух других случаях в исходном конфликте произошло убийство. В основе первого конфликта, возникшего между жителями селения Куба, М.К. и Х.М., в 1930-е годы, были, как сказано в архивном деле, личные неприязненные отношения. Между ними происходили мелкие ссоры, оскорбления, драки. 31 августа 1931 г. оба прибыли в Нальчик на слет ударников республики. В перерыве между совещаниями М.К. ножом убил Х.М. Верховный Суд республики осудил М.К. на 10 лет заключения. В это время жена потерпевшего была беременна и в 1932 г. у нее родился сын В.М. Мальчик вырос и узнал об обстоятельствах убийства своего отца. Мать показала сыну сохранившуюся окровавленную рубашку. В 1942 г. убийца, отсидев свой срок, вернулся в родное селение. Через несколько лет в селении пропал старший брат В.М. - Н.М. Его родственники и сельчане подозревали в этом М.К. Первое столкновение между В.М. и М.К. произошло в 1951 г. К этому времени В. стал работать милиционером, а М.К. - муллой. Мать, боясь дальнейших столкновений, уговорила сына покинуть селение и поселиться в г. Нальчике. Тем не менее кровники неожиданно встретились во время похорон родственника. М.К., увидя В.М., начал вести себя вызывающе: он сказал В.М.: «Смотрите на эту скотину, он молод, но уже седой». Позже, на суде В.М. сказал, что он не мог вынести встречи с убийцей своего отца и подобного оскорбления от него. В.М. нанес 7 ножевых ранений М.К., от которых тот умер. После убийства В.М. рассказал матери о случившемся, добровольно пришел в милицию и сообщил, что совершил убийство на почве мести за убийство своего отца².

Введение советских норм судопроизводства оказало влияние на появление новых черт в традиционном правовом сознании кабардинцев. Изучая уголовные дела по изнасилованиям, мы пришли к выводу, что кабардинцы восприняли советские правоохранительные и судебные органы не как учреждения, в которые они обязаны обращаться в определенных ситуациях, а как средство оказания давления на участников конфликта. В тех случаях, когда насильник не торопился предложить потерпевшей выйти за него замуж, ее родственники обращались в правоохранительные органы с заявлением, в котором они просят возбудить уголовное дело против насильника только в том случае, если он откажется жениться на потерпевшей ${ }^{3}$. Данный факт показывает, что, с одной стороны, кабардинцы, безусловно, не признавали советские правоохранительные и судебные органы как обязательные, а с другой, он свидетельствует о том, что они сумели найти в своей практике урегулирования споров нишу и для советской правовой системы и включили ее в свой арсенал способов оказания воздействия на участников конфликта.

Основная проблема, с которой сталкивались судьи, адвокаты и прокуроры во время судебных процессов, состояла в правильной классификации категории убийств на почве кровной мести. Для этого суду следовало ответить на два вопроса: 1) совершено ли убийство по мотиву кровной мести, 2) можно ли предполагаемого виновного отнести к группе населения, среди которой распространен обычай кровной мести. Исходя из вариантов ответа на эти вопросы, убийство можно было квалифицировать либо по ст.102 как убийство при отягчающих обстоятельствах, либо по ст.103 как убийство без таковых. Ответ на первый вопрос искали сотрудники правоохранительных и судебных органов в ходе дознания 4 , а для получения ответа на второй вопрос Верховный суд КБР обращался в 1960-е годы и обращается до сих пор к ученым с просьбой о предоставлении им научной экспертизы, в которой они обязаны ответить на следующий вопрос: «Исторически

\footnotetext{
${ }^{1}$ Архив ВС КБР. Д.4-Н-65.

2 Архив ВС КБР. Д.21-05-22. Т.1-2

${ }^{3}$ Архив ВС КБР. Д. 10/6., Л. 101.

${ }^{4}$ Архив ВС КБР. Д.2-29, 21-05-22. Т.1-2.
} 
сложился ли обычай кровной мести и был ли он признан и какой группой населения в Кабардино-Балкарии?». Местные ученые из Научно - исследовательского института гуманитарных наук КБР (ранее - Института истории, филологии и экономики), составлявшие подобные документы, подчеркивали, что у кабардинцев и балкарцев институт кровной мести был распространен и имел общественное значение только в прошлые века и после 1917 г. перестал функционировать. Поэтому вряд ли можно, заключали ученые, кабардинцев и балкарцев относить к группе населения, признающих кровную месть.

Такую же позицию занимали адвокаты подсудимых. Так, в одной Кассационной жалобе адвоката В.М. в Судебную коллегию по уголовным делам ВС РСФСР было подчеркнуто, что «факты проявления в отдельных местностях КБАССР тех нравов и обычаев далекого прошлого, свойственное родовому строю и патриархально-феодальному быту, как обычай кровной мести» отсутствуют. В КБР кровная месть уже перестала быть обычаем. По мнению адвоката, «убийство на почве кровной мести предполагает наличие в сознании виновного пережитков далекого прошлого», тогда как в народном правосознании уже давно нет места кровной мести как варианту продолжения исходного конфликта. Поэтому адвокаты предлагали суду рассматривать подобные убийства не как убийства на почве кровной мести, а как убийства на почве сложившихся неприязненных отношений, что позволяло квалифицировать их по 103 ст. ${ }^{1}$

Местные советские правоохранительные органы проводили политику невмешательства во внутрисельские конфликты. Во-первых, известно, что преступления на почве кровной мести, как правило, готовились открыто В тех случаях, когда правоохранительные органы знали о готовящемся убийстве, они не предпринимали никаких мер по его предупреждению и не возбуждали уголовных дел за недоносительство. Во-вторых, сельчане, знавшие детали уже совершившегося преступления на почве кровной мести, отказывались предоставлять информацию в правоохранительные органы, что, безусловно, было связано с боязнью совершения над ними мести. Местные жители не называли имен преступников, а если и называли в редких случаях, то отказывались помогать в их розыске и задержании. Виновные в совершении убийств не всегда сообщали о реальной причине преступления на суде, поскольку умышленное убийство рассматривалось как более тяжкое ${ }^{2}$.

Верховный суд КБР не обращал в 1950-1970-е годы внимание на информацию о попытке или факте дачи кабардинцами или балкарцами (родственниками обвиняемых) компенсации (выкупа) семьям потерпевших. Подобные действия горцев в 1920-1930-е годы жестоко преследовались советскими правоохранительными и судебными органами. Позднее республиканские и федеральные органы стали относиться к применению этой нормы традиционного права терпимо, почти без внимания, лишь изредка отмечая данный факт в судебном приговоре 3 .

Советская правовая система оказала лишь частичное влияние на уровень сельской конфликтности, поскольку осуждение виновного в совершении любого уголовного преступления советским судом ни к коей мере не освобождало его и его семью от угрозы совершения кровной мести со стороны родственников потерпевшего. Как отмечали правоведы и прокуроры, даже при осуждении виновного советским судом к смертной казни родственники убитого все равно совершали кровную месть по отношению к кому-либо из членов семьи виновного [4]. Известны случаи, когда советский суд осуждал виновного, а его семье не удавалось примириться с семьей потерпевшего, то обязательно следо-

\footnotetext{
${ }^{1}$ Архив ВС КБР. Д.21-05-22. Т.2. Л.63, 64.

2 Архив ВС КБР. Д. 22041.

${ }^{3}$ Архив ВС КБР. Д. 21-06-19, 1520.
} 
вала месть в какой-либо форме. Освобождение от мести могло быть осуществлено только после медиаторского примирения.

Поэтому иногда кабардинцы, родственники потерпевшего, во время судебного заседания выражали просьбы об определении более мягкого приговора виновному. Однако чаще всего потерпевший или его родственники просили суд назначить виновному смертную казнь, утверждая, что в противном случае они совершат над виновным кровную месть. В 1950-70-е годы возникла новая форма мести, когда потерпевший или его родственники просили народный суд, в котором рассматривалось дело, назначить виновному смертную казнь, утверждая, что в противном случае они сами совершат над ним кровную месть ${ }^{1}$. Кабардинцы пытались ввести в советское судопроизводство и другую норму адата, а именно: выселение семьи виновного на жительство в другое селение. Мы обнаружили в архиве Верховного суда КБР целый ряд дел, в которых родственники потерпевших просили суд о применении подобного наказания. Особенно это касалось тех случаев, когда участники конфликта жили по соседству. Жена одного убитого кабардинца, требуя выселения семьи виновного из селения, говорила на суде: «мы живем близ друг друга и я не хочу, чтобы дети выросли с чувством мести»².

Сельчане пытались влиять и на ход судебного процесса. Еще до судебного заседания они проводили собрание, на котором обсуждались обстоятельства совершенного преступления и принималось решение об оказании общественной поддержки либо родственникам потерпевшей, либо родственникам обвиняемого. Данный документ отправлялся в советский (российский) суд. Иногда кто-либо из сельчан зачитывал его во время заседания суда. Случалось, что сельчане просили о снисхождении членов суда к виновному. Так, в одном подобном документе говорилось, что сельчане близко знают семьи виновного и потерпевшей, что семья виновного взяла на себя воспитание потерпевшей до ее совершеннолетия 3 . Как нам представляется, попытка сельчан участвовать не только в медиаторском процессе, но и в советском судебном заседании, свидетельствует о сохранении элементов коллективного правосознания и об особенностях восприятии горцами советских судебных органов.

\section{Заключение}

Таким образом, мы видим, что на Северном Кавказе в 1950-70-е гг. происходит трансформация правовой культуры горцев региона. В одних республиках (Чечня и Ингушетия) на новом витке на государственном уровне вновь создавались Примирительные комиссии. На Северо-Западном и Центральном Кавказе усилились тенденции к примирению традиционного медиаторства с выплатой компенсаций. Обе правовые модели все более и более отходили друг от друга в контексте заложенных в них принципов деятельности. Тем не менее, их применение на практике проходило с большей или меньшей успешностью.

\section{Литература}

1. Бабич И.Л., Плиев А.А. Примирительные комиссии на Северном Кавказе в 192030-е гг.: сравнительный анализ // Северо-Кавказский юридический вестник. 2019. № 2. C. 29-40.

2. Албогачиева М. С.-Г. Бабич И.Л. Правовая культура ингушей: история и современность // История государства и права. 2009. № 19-20.

3. Бабич И.Л. Иерархия общественных статусов в кабардинском обществе // Этнографическое обозрение. 1994. № 4. С. 44-53.

\footnotetext{
${ }^{1}$ Архив ВС КБР. Д. 2210, 2-44, 2801, 10/67, 5372, 21-05-22. Т.1-2; АИЭА. Тетр.2. Оп.1. Д.5.

${ }^{2}$ Архив ВС КБР. Д. 12/300, Л.352; 2-44, Л.149.

${ }^{3}$ Архив ВС КБ. Там же. Д. 10/60, 1360.
} 
4. Полевые материалы И.Л. Бабич (АИЭА). 1990-2010 гг.

5. Полевые материалы Л.К. Гостиевой. 2000 г.

6. Феномен культуры в российской общественной географии (экспертные мнения, аналитика, концепты). Ростов на Дону, 2014.

Babich Irina Leonidovna, Doctor of History, Chief Researcher, Institute of Ethnology and Anthropology, Russian Academy of Sciences (32-A, Leninsky Ave, Moscow, 119334, Russian Federation). E-mail: babi7chi@yandex.ru

Pliev Abdurakhim Ahmedovich, candidate of historical sciences, Institute of Ethnology and Anthropology, Russian Academy of Sciences (32-A, Leninsky Ave, Moscow, 119334, Russian Federation). E-mail: babi7chi@yandex.ru

\title{
MODELS OF MEDIATION IN THE NORTH CAUCASUS IN THE 1950 -1970
}

\begin{abstract}
The aim of this article is to study the formation of models of mediation in the $1950-70$, when the Soviet government in the post-war, Khrushchev' period drew attention to the mountain adat. The study is based on the analysis of criminal cases of the Supreme Courts of the Kabardino-Balkarian and Chechen-Ingush and other archival and field materials. The authors of this article discusses the principles of creating Soviet reconciliation commissions in Chechnya and Ingushetia and the basics of mediation among Circassians and Ossetians, as well as the interaction the blood feud and Soviet proceedings.
\end{abstract}

Keywords: North Caucasus, mediation, conciliation commissions, Soviet power, the elderly.

\section{References}

1. Babich I.L., Pliev A.A. Primiritel'nye komissii na Severnom Kavkaze v 1920-30-e gg.: sravnitel'nyj analiz // Severo-Kavkazskij yuridicheskij vestnik. 2019 № 2. S.29-40.

2. Albogachieva M. S.-G. Babich I.L. Pravovaya kul'tura ingushej: istoriya i sovremennost' // Istoriya gosudarstva i prava. 2009. № 19-20.

3. Babich I.L. Ierarhiya obshchestvennyh statusov v kabardinskom obshchestve // Etnograficheskoe obozrenie. 1994. № 4. S. 44-53.

4. Polevye materialy I.L. Babich (AIEA). 1990-2010 gg.

5. Polevye materialy L.K. Gostievoj. 2000 g.

6. Fenomen kul'tury v rossijskoj obshchestvennoj geografii (ekspertnye mneniya, analitika, koncepty). Rostov na Donu, 2014. 